\title{
ОСОБЕННОСТИ ПРОЦЕССОВ НАКОПЛЕНИЯ И МЕТАМОРФИЗМА ТРИАСОВЫХ МЕТАЛЛОНОСНЫХ ОСАДКОВ В ТАУХИНСКОМ И САМАРКИНСКОМ ТЕРРЕЙНАХ СИХОТЭ-АЛИНЯ (по результатам изучения геохимии и минералогии Th, U и REE)
}

\author{
В. Т. Казаченко, Е. В. Перевозникова \\ Дальневосточный геологический институт ДВО РАН, г. Владивосток \\ Поступила в редакцию 28 марта 2018 г.
}

\begin{abstract}
Аннотация: монацит, алланит, обогащченный $\mathrm{REE}$ апатит и соединение $\mathrm{Dy}_{2} \mathrm{O}_{3}$, а также минералы Th и U кристаллизовались в проиессе контактового метаморфизма металлоносных осадков в тех же условиях, что и породообразуюшие минераль марганцевосиликатных пород и силикатномагнетитовых руд. Присутствие соединения $\mathrm{Fe} \mathrm{e}_{2} \mathrm{Ce}$, также как и многих других интерметаллических соединений и самородных элементов объясняется влиянием органического вещества подстилающих углеродистых силищитов. Оно связано с удалением из углеродистых пород при нагревании наиболее летучих компонентов, в первую очередь, плохо связанной воды и углеводородов, $u$ возникновению, таким образом, некоторого объема флюида с высоко и ультравосстановительнылм способностями, мигрировавщего по трещинам в другие породы. Различия по Th-U отношению, а также присутствие в REE-спектрах марганцевосиликатных пород Самаркинского террейна положительной Се аномалии, а в REE-спектрах Таухинского террейна отрицательной Се и положительной Еи аномалий, связаны с различиями в фациальных условиях осадконакопления (определявшимися разным положением относительно окраины Ханкайского массива) и степенью влияния подвижной метаморфогенной флюидной фазы при контактовом метаморфизме.
\end{abstract}

Ключевые слова: металлоносные осадки, редкоземельные элементы, торий, уран, триас, Таухинский террейн, Самаркинский террейн, Сихотэ-Алинь.

\section{PECULIARITIES OF ACCUMULATION AND METAMORPHISM OF THE TRIASSIC METALLIFEROUS SEDIMENTS IN THE TAUKHA AND SAMARKA TERRANES OF THE \\ SIKHOTE-ALIN (by the results of geochemical and mineralogical study of Th, $\mathrm{U}$ and REE)}

\begin{abstract}
REE, the $\mathrm{Dy}_{2} \mathrm{O}_{3}$, compound, and Th and U minerals were crystallized in the process of the contact metamorphism of metalliferous sediments under the same conditions as the rock-forming minerals of manganese-silicate rocks and silicate-magnetite ores. The presence of the $\mathrm{Fe}_{2} \mathrm{Ce}$ compound as well as many other intermetallic compounds and native elements is explained by the influence of the organic matter of the underlying carbonaceous silicites. It is connected with the removal from the carbonaceous rocks through heating of the most volatile components, and first of all the poorly bound water and hydrocarbons, that resulted in the origination of some fluid volume with high-and ultra-reductive capacity, which migrated along fractures to other rocks.Differences in the Th- $U$ ratio and the presence of the positive Ce anomaly in the REE-spectra of the manganese-silicate rocks of Samarka terrane and the negative Ce and positive Eu anomalies in the REE-spectra of Taukha terrane are related with the differences in the facial conditions of sedimentation (defined by different position relative the margin of Khanka massif) and with the extent of influence of the mobile metamorphogenetic fluid phase through the contact metamorphism.
\end{abstract}

Key words: metalliferous sediments, rare-earth elements, thorium, uranium, the Triassic, Taukha terrane, Samarka terrane, the Sikhote-Alin.

\section{Введение}

Метаморфизованные триасовые металлоносные осадки - марганцевосиликатные породы и силикатномагнетитовые руды, изначально являлись продуктами размыва латеритной коры выветривания габброидов калиновского, сергеевского и владимиро-александ- ровского комплексов, накапливавшимися вместе с кремнистыми илами в прилегавших к островам акваториях [1]. Габброиды этих комплексов имеют общий мантийный источник магм - примитивную мантию (BSE), и образовались в результате взаимодействия плюма с осадочными породами океанической коры в 
основании островной дуги (сергеевские и владимироалександровские габброиды) или океанических плато (калиновские) [2]. Во время юрской и меловой аккреций металлоносные осадки в составе фрагментов триасовой кремневой формации были включены в Самаркинский и Таухинский террейны, соответственно. При внедрении гранитоидных интрузий ХунгариТатибинского плутонического (ранний мел) и Восточно-Сихотэ-Алинского вулкано-плутонического (поздний мел) поясов они испытали контактовый метаморфизм [3].

Триасовая кремневая формация сложена кремнями, кремневыми аргиллитами, аргиллитами и алевроаргиллитами. Местами в ней присутствуют известняки, мергели, глинистые и кремнистые известняки. Ее особенностью является наличие яшм, углеродистых разностей кремнистых и кремнисто-глинистых пород, а также контактово-метаморфизованных металлонос- ных осадков (марганцевосиликатных пород и силикатно-магнетитовых руд), приуроченных к определенным стратиграфическим горизонтам. Нижняя часть формации сложена смятой в крупные складки «глинисто-кремнистой» толщей (оленек-средний анизий), обогащенной прослоями углеродистых разностей пород и согласно перекрытой «кремневой» толщей светло-серых плитчатых кремней. В основании последней присутствует горизонт яшм (верхний анизий-ладинский ярус) мощностью более 3 м. Вышележащие кремни относятся к карнию и норию.

Многочисленные (более трех десятков) выходы триасовых метаморфизованных металлоносных осадков изучены на Горной (Самаркинский), Широкопаднинской, Мокрушинской и Садовой (Таухинский террейн) площадях (рис. 1). На Высокогорской площади (Таухинский террейн) известны только слабо метаморфизованные аналоги марганцевосиликатных пород

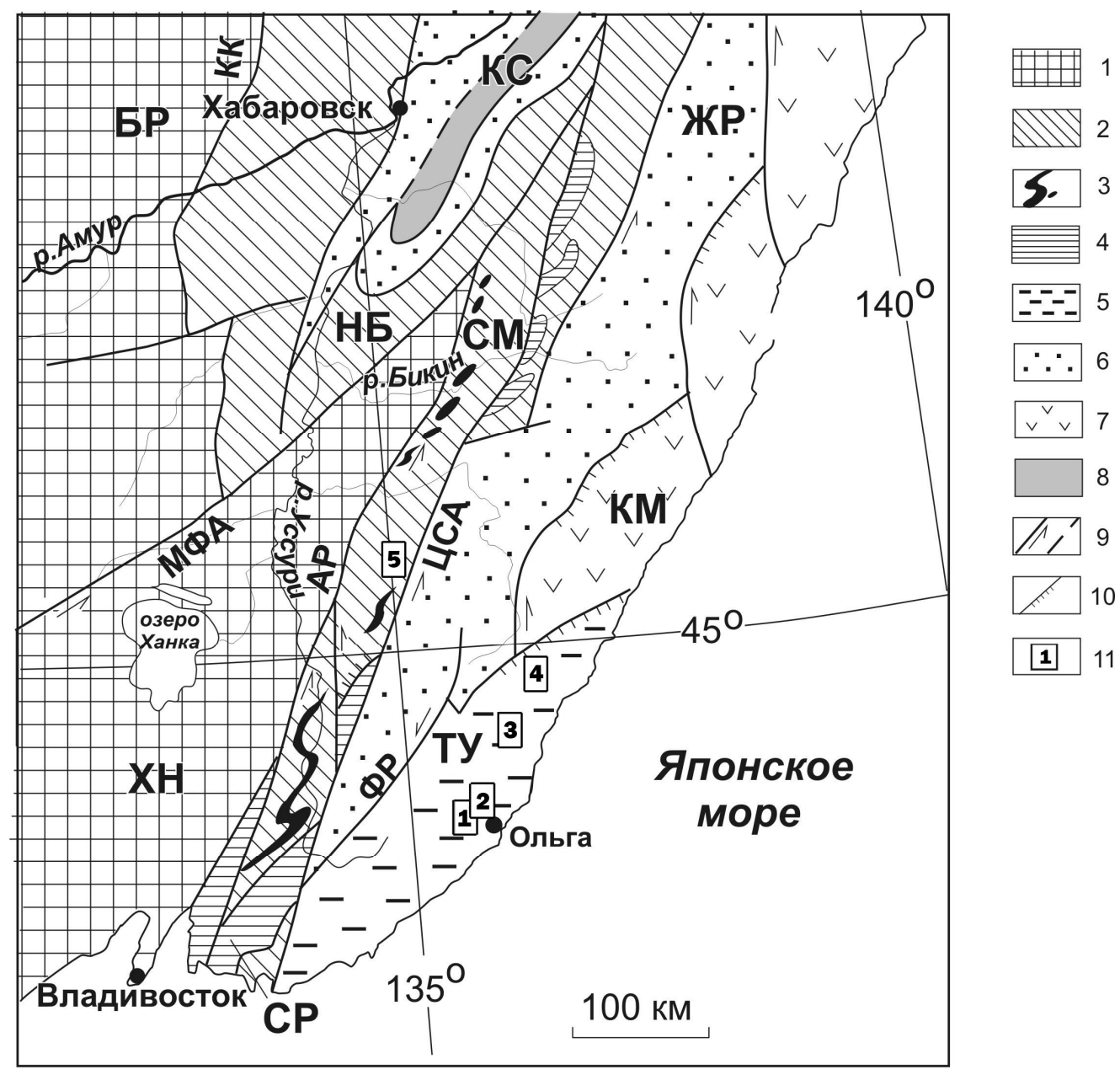

Puc. 1. Положение изученных площадей в Сихотэ-Алине. Тектоническая основа по Ханчуку А. И. [4] с небольшими изменениями: 1 - ХН - Ханкайский массив, БР - Буреинский массив; 2 - юрские террейны (фрагменты аккреционных призм): СМ Самаркинский, НБ - Наданьхада-Бикинский; 3 - калиновские габброиды (девон?); 4 - Окраинско-Сергеевский террейн (СР) и его фрагменты, включенные в структуры юрской аккреционной призмы и испытавшие вместе с ними цикл син- и постаккреционных преобразований; 5, 6 - раннемеловые террейны-фрагменты: 5 - неокомовской аккреционной призмы (ТУ - Таухинский); 6 - приконтинентального спредингового турбидитового бассейна (ЖР -Журавлевско-Амурский); 7 - баррем-альбской островодужной системы (КМ - Кемский); 8 - альбской аккреционной призмы (КС - Киселевско-Маноминский); 9 - левые сдвиги, в том числе: КК - Куканский, АР - Арсеньевский, МФА - Мишань-Фушуньский (Алчанский), ЦСА - Центральный Сихотэ-Алинский, ФР - Фурмановский; 10 - надвиги; 11 - изученные площади с выходами триасовых контактово-метаморфизованных металлоносных осадков: 1 - Широкопаднинская, 2 - Мокрушинская, 3 - Высокогорская, 4 - Садовая, 5 - Горная. 
- кремнисто-родохрозитовые породы. Марганцевосиликатные породы и силикатно-магнетитовые руды слагают линзообразные и пластовые тела мощностью от нескольких десятков сантиметров до нескольких метров и протяженностью по простиранию десяткипервые сотни метров, занимающие стратифицированное (одинаковое на всех изученных площадях Таухинского и Самаркинского террейнов) положение в разрезе триасовых отложений $[5,6]$. Вместе с яшмами они образуют общую пачку (рис. 2) или фациально сменяют друг друга по простиранию. На поверхности выходы триасовых металлоносных осадков, группирующиеся в серии протяженных линейных зон, параллельных простиранию вмещающих пород, маркируют выходы смятого в складки марганценосного горизонта (рис. 3). Некоторые зоны прослежены авторами по отдельным выходам на расстоянии до 4,3 км. Марганцевосиликатные породы вместе с яшмами и стратифицированными силикатно-магнетитовыми рудами приурочены к основанию «кремневой толщи». Они встречаются только в контактовых ореолах гранитоидных интрузий Восточно-Сихотэ-Алинского интрузивно-вулканогенного пояса (поздний мел-палеоген) в Таухинском террейне, и Хунгари-Татибинского интрузивного комплекса (ранний мел) в Самаркинском террейне, за пределами которых сменяются кремнями с дисперсным родохрозитом. Марганцевосиликатные породы образовались в результате контактового метаморфизма кремней с дисперсным родохрозитом (продуктов диагенеза богатых марганцем биогенных кремнистых илов) [3]. Одинаковое положение метаморфизованных металлоносных осадков в разрезе триасовых отложений Таухинского и Самаркинского террейнов свидетельствует о синхронном накоплении исходных богатых марганцем и железом осадков в едином осадочном бассейне. В Таухинском террейне контактовый метаморфизм продуктов диагенеза металлоносных осадков, связан-

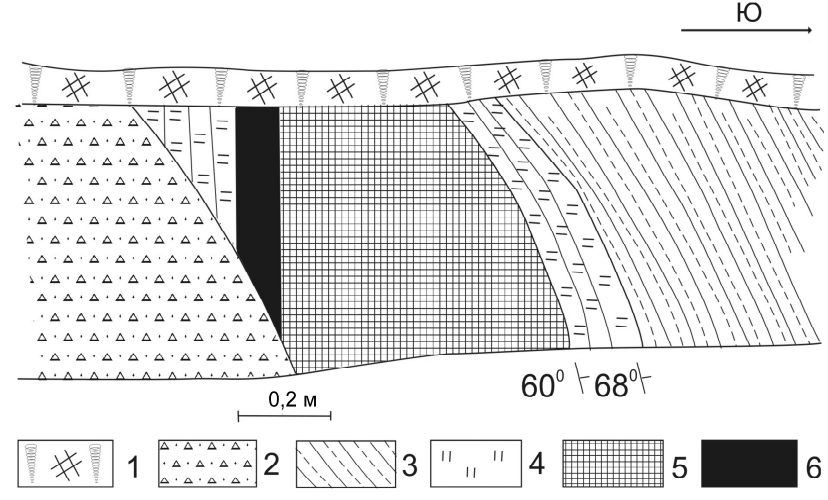

Puc. 2. Характер залегания и строение рудоносной пачки на Широкопаднинской площади Ольгинского района (рудопроявление 19) [6] с дополнениями и изменениями: 1 - почвенно-растительный слой; 2 - делювий; 3 - кремнисто-глинистые породы; 4 - яшмы; 5 - марганцевосиликатные породы; 6 силикатно-магнетитовые руды.

ный с гранитоидами Восточно-Сихоте-Алинского интрузивно-вулканогенного пояса, происходил в позднем мелу-палеогене. В Самаркинском террейне марганцевосиликатные породы образовались в раннемеловое время при формировании крупных гранитоидных тел Хунгари-Татибинского комплекса.

На некоторых участках метаморфизм триасовых металлоносных осадков протекал с участием подвижной метаморфогенной флюидной фазы, вследствие чего происходило перераспределение их вещества во вмещающие кремнистые породы вдоль систем трещин. Это приводило к преобразованию пластовых и линзовидных тел кремней с дисперсным родохрозитом в метасоматические штокверкоподобные системы марганцевосиликатных пород. Подробно этот процесс, протекавший с участием литифицированных металлоносных осадков и вмещающих их кремней без заметного привноса инородного вещества, был подробно рассмотрен ранее [5].

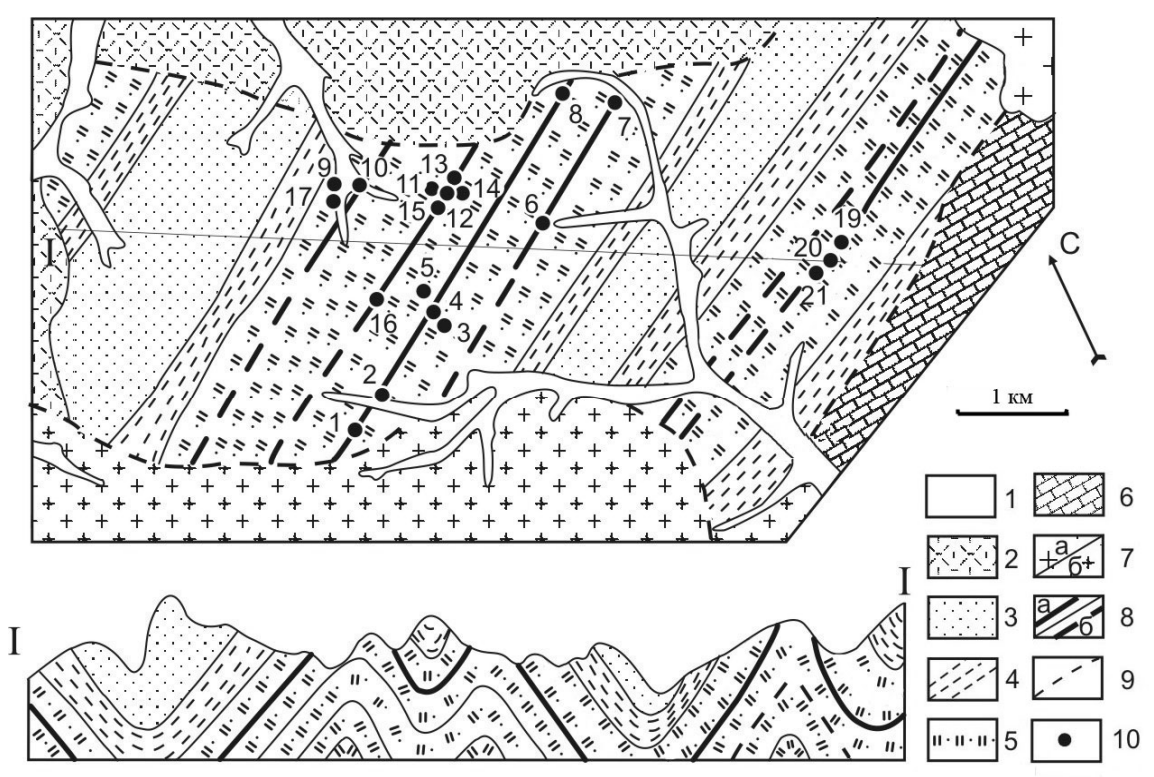

Puc. 3. Схема геологического строения Широкопаднинской площади [5] с изменениями и дополнениями: 1 - четвертичные отложения; 2 - вулканиты Восточно-Сихотэ-Алинского вулканогенного пояса; 3 - песчаниковая толща (К1?); 4 пелит-алевролитовая толща с горизонтами туффитов, кремнистых пород и песчаников (J2-3); 5 - глинисто-кремнистые отложения среднегопозднего триаса; 6 - карбон-пермские кремнисто-глинистые отложения и рифовые известняки; 7 - граниты Владимирского (а) и Широкопаднинского (б) массивов (поздний мел); 8 - рудоносная пачка (марганцевосиликатные породы, силикатномагнетитовые руды, яшмы): $a-$ установленное местоположение, б предполагаемое; 9 - разрывные нарушения; 10 - установленные выходы марганцевосиликатных пород. 
Марганцевосиликатные породы сложены диопсидом, бустамитом, родонитом, пироксмангитом, спессартином, тефроитом, Ва-содержащим флогопитом, гиалофаном, цельзианом, марганцовистыми амфиболами тремолит-ферроактинолитового и куммингтонит-грюнеритового ряда, манганпиросмалитом и другими минералами [3]. Им свойственны различия в ассоциациях, обусловленные, главным образом, региональными вариациями содержания Са и щелочей в исходных отложениях, с которыми коррелируют различия по степени распространения тех или иных минеральных форм REE и Th-U отношению (см. ниже). Силикатно-магнетитовые руды имеют тальк-магнетитовый, манганактинолит-магнетитовый и хлоритмагнетитовый состав.

Марганцевосиликатные породы и силикатно-магнетитовые руды обогащены $\mathrm{Sn}, \mathrm{Au}, \mathrm{Ag}, \mathrm{Pt}, \mathrm{Pd}, \mathrm{Zn}, \mathrm{Pb}$, $\mathrm{W}, \mathrm{Cu}, \mathrm{V}, \mathrm{Co}, \mathrm{Ni}$, As, редкоземельными и другими металлами. Эти особенности состава в значительной степени предопределили разнообразие минеральных форм второстепенных элементов. В виде сингенетических микровключений в породообразующих минералах присутствуют касситерит, станнин, шеелит, вольфрамит, вульфенит, циркон, бадделиит, самородные золото, серебро и платина, сперрилит, а также сульфиды $\mathrm{Fe}, \mathrm{Zn}, \mathrm{Cu}$ и $\mathrm{Pb}$, арсениды, антимониды, теллуриды, сульфоарсениды, сульфоантимониды, сульфовисмутиды и сульфотеллуриды $\mathrm{Ni}$ и $\mathrm{Co}$, кислородсодержащие редкоземельные, торий-урановые, ванадиевые и другие минералы. Наряду с ними характерны разнообразные самородные элементы, неупорядоченные твердые растворы металлов и интерметаллические соединения, приуроченные, главным образом, к порам и микротрещинам с органическим веществом и кристаллизовавшиеся в особых, высоко и ультравосстановительных условиях [3].

Метаморфизованные триасовые металлоносные осадки Сихотэ-Алиня представляют большой научный интерес. Предшествующие исследования марганцевосиликатных пород и силикатно-магнетитовых руд способствовали выяснению основных событий раннего периода (с середины девона до конца триаса) геологической истории этой структуры, оказавших определяющее влияние на ее металлогению $[1,2]$. Результаты изучения марганцевосиликатных пород Сихотэ-Алиня позволили также уточнить и расширить существующие представления о процессах и геологических обстановках накопления рудных концентраций Мn и источниках этого металла. Они дали возможность проследить особенности эволюции марганцеворудных накоплений от металлоносных осадков через марганцевые руды карбонатного типа до марганцевосиликатных пород, то есть нерудных (из-за силикатной формы Mn) образований [3]. Марганцевосиликатные породы могут представлять и практический интерес с учетом содержаний $\mathrm{Au}, \mathrm{Ag}, \mathrm{Pt}$ и Pd [7], а также в качестве ценного ювелирно-поделочного камня (родонита), а сменяющие их за пределами контактовых ореолов кремни с дисперсным родохрозитом - в качестве возможного сырья для из- влечения Mn. Практический интерес к силикатномагнетитовым рудам обусловлен заслуживающими внимания концентрациями $\mathrm{Fe}, \mathrm{Sn}, \mathrm{Au}$ и платиноидов. Горными выработками выходы триасовых металлоносных осадков почти не изучены (при поисковоразведочных работах на родонит канавами было вскрыто лишь несколько мелких тел), поэтому даже приблизительная оценка их практической значимости не представляется возможной.

Целью данной работы являлось изучение геохимии и минералогии Th, U и REE и выяснение на основе полученных данных возможных различий в условиях накопления и контактового метаморфизма металлоносных осадков двух крупных структур СихотэАлиня - Таухинского и Самаркинского террейнов.

\section{Методика аналитических исследований}

Определение содержаний второстепенных элементов в марганцевосиликатных породах и силикатномагнетитовых рудах (табл. 1) выполнено в Хабаровском инновационно-аналитическом центре ИТИГ ДВО РАН методом масс-спектрометрии с индуктивно-связанной плазмой на спектрометре ICP-MS Elan DRC II PerkinElmer (США). Особенностью методики являлось кислотное разложение проб в микроволновом поле.

Анализы минералов (в аншлифах) выполнены в ДВГИ ДВО РАН на рентгеноспектральном микроанализаторе «ЈХА8100» с тремя волновыми спектрометрами и энергодисперсионным спектрометром INCAxsight (табл. 2-4) по методике, принятой в этой организации. Присутствующие в анализах (из-за малой размерности зерен минералов) содержания породообразующих элементов при расчете формул во внимание не принимались.

\section{Результаты исследований}

Наиболее высокие средние содержания и средняя сумма REE характерны для марганцевосиликатных пород Таухинского террейна (см. табл. 1). Аналогичные породы Самаркинского и силикатно-магнетитовые руды Таухинского террейнов сопоставимы по этим параметрам. Наиболее высокие значения средних содержаний Th и U свойственны силикатномагнетитовым рудам. Наиболее высоким значением среднего Th-U отношения отличаются марганцевосиликатные породы Таухинского, а наиболее низким аналогичные породы Самаркинского террейна.

В марганцевосиликатных породах минералы REE (см. табл. 2, 3) представлены, главным образом, монацитом или алланитом. Значительно реже встречаются гидроксилбастнезит и минерал, который, после исключения из его анализов содержаний (в основном, небольших) «прихваченных» породообразующих элементов, может быть отнесен только к оксиду или гидроксиду Ce и La. Из-за присутствия в некоторых анализах небольших содержаний $\mathrm{F}$ и $\mathrm{Cl}$, указывающих, очевидно, на наличие гидроксильной группы, он в данной работе условно именуется гидроксидом (Ce,La)O(OH,F,Cl). Обнаружено также соединение, анализ которого пересчитывается на идеальную формулу $\mathrm{Fe}_{2} \mathrm{Ce}$. 


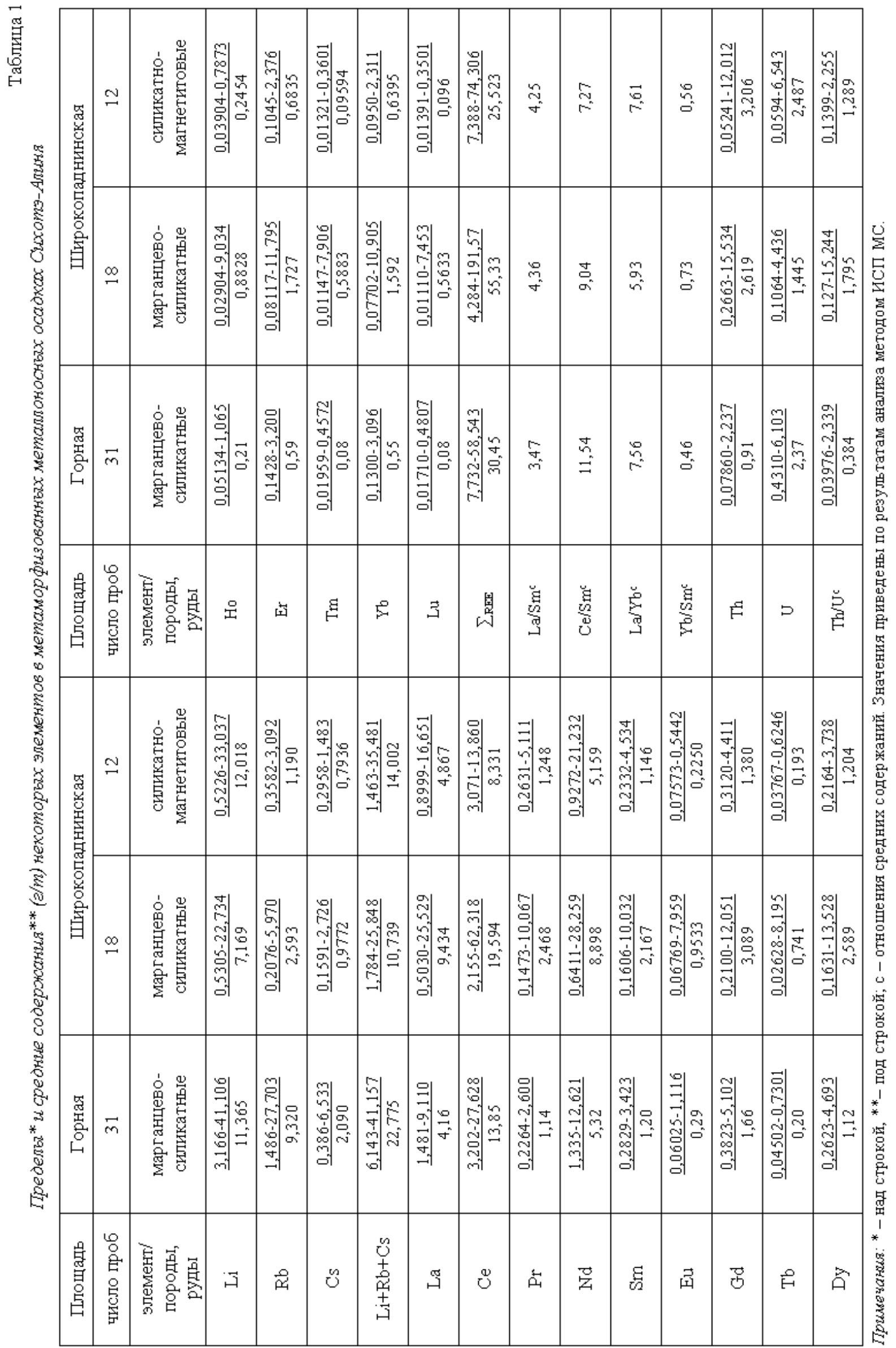


Таблица 2

Результаты изучения состава (мас. \%) минералов марганщевосиликатных пород Таухинского террейна

\begin{tabular}{|c|c|c|c|c|c|c|c|c|c|c|c|c|c|}
\hline № п/п & $\mathrm{O}$ & $\mathrm{Al}$ & $\mathrm{Si}$ & $\mathrm{P}$ & $\mathrm{Ca}$ & $\mathrm{Mn}$ & $\mathrm{Fe}$ & $\mathrm{La}$ & $\mathrm{Ce}$ & $\mathrm{Nd}$ & $\mathrm{Th}$ & $\mathrm{U}$ & Сумма \\
\hline 1 & 35,27 & 11,69 & 10,68 & 6,44 & 0,6 & 2,44 & 0,91 & 9,03 & 12,79 & 4,17 & 1,79 & & 96,99 \\
\hline 2 & 28,73 & 0,34 & 3,02 & 11,9 & 0,31 & & & 12,03 & 26,31 & & 2,3 & & 96,71 \\
\hline 3 & 26,22 & & 1,43 & 11,32 & 0,45 & 4,91 & & 14,38 & 31,88 & 4,48 & 1,9 & & 97,97 \\
\hline 4 & 35,96 & 7,75 & 14,35 & & 6,6 & 5,35 & 8,31 & 5,11 & 10,33 & 2,5 & & & 96,53 \\
\hline 5 & 43,07 & 6,93 & 14,39 & & 8,08 & 4,82 & 6,51 & 3,49 & 8,78 & 1,96 & & & 98,85 \\
\hline 6 & 39,70 & 9,05 & 14,98 & & 9,01 & 2,40 & 8,75 & 2,50 & 6,52 & 1,94 & & & 95,14 \\
\hline 7 & 19,85 & & 1,55 & & 0,75 & & 16,81 & 25,31 & 31,96 & & & & 97,1 \\
\hline 8 & 25,16 & & 20,86 & & & & 23,33 & & 30,66 & 10,57 & & & 100,01 \\
\hline 9 & 16,68 & & 4,69 & & 1 & 5,52 & 0,47 & 18,05 & 31,72 & 7,61 & & & 88,63 \\
\hline 10 & 30,88 & 0,31 & 20,53 & & 0,54 & & & & & & 42,34 & 13,23 & 107,72 \\
\hline 11 & 25,76 & & 22,6 & & & & & & & & 32,3 & 23,07 & 103,74 \\
\hline 12 & 35,07 & & 22,18 & & 2,09 & 11,89 & 3,45 & & & & 19,37 & 5,96 & 100,01 \\
\hline 13 & 35,13 & 1,08 & 15,89 & & 1,4 & 3,67 & 0,51 & & & & 40,97 & 3,64 & 100,3 \\
\hline 14 & 10,43 & & 0,37 & & & 1,12 & & & & & 17,7 & 70,71 & 100,34 \\
\hline 15 & 12,29 & & & & & 4,12 & & & & 1,36 & 13,19 & 72,48 & 103,44 \\
\hline 16 & 33,47 & & 14,63 & & & 0,78 & & & & & & 5,48 & 98,76 \\
\hline
\end{tabular}

Примечания: кроме того, в ан. 1- 0,74 K и 0,44 Mg; 4- 0,27 Mg; 7 - 0,85 Cr; 8-1,22 Sm; 9 - 2,89 Pr; 16 - 44,41 Zr. Минералы: монацит (1-3), алланит (4-6), гидроксид (7), $\mathrm{Fe}_{2} \mathrm{Ce}(8)$, бастнезит (9), торианит (10-13), бреггерит $(14,15)$, циркон (16). Формулы: 1 - $\left(\mathrm{Ce}_{0,44} \mathrm{La}_{0,31} \mathrm{Nd}_{0,14} \mathrm{Ca}_{0,07} \mathrm{Th}_{0,04}\right)_{1,00} \mathrm{P}_{1,00} \mathrm{O}_{4} ; 2-\left(\mathrm{Ce}_{0,50} \mathrm{La}_{0,23} \mathrm{Nd}_{0,19} \mathrm{Sm}_{0,02} \mathrm{Th}_{0,03} \mathrm{Ca}_{0,02}\right)_{0,99} \mathrm{P}_{1,01} \mathrm{O}_{4}$;

$3-\left(\mathrm{Ce}_{0,60} \mathrm{La}_{0,28} \mathrm{Nd}_{0,08} \mathrm{Ca}_{0,03} \mathrm{Th}_{0,02}\right)_{1,01} \mathrm{P}_{0,99} \mathrm{O}_{4} ; 4-\left(\mathrm{Ca}_{0,98} \mathrm{Mn}_{0,26} \mathrm{Ce}_{0,44} \mathrm{La}_{0,22} \mathrm{Nd}_{0,10}\right)_{2,00}\left(\mathrm{Al}_{1,71} \mathrm{Fe}_{0,88} \mathrm{Mn}_{0,32} \mathrm{Mg}_{0,07}\right)_{2,98} \mathrm{Si}_{3,03} \mathrm{O}_{12}(\mathrm{O}, \mathrm{OH})$;

$5-\left(\mathrm{Ca}_{1,26} \mathrm{Mn}_{0,11} \mathrm{Ce}_{0,39} \mathrm{La}_{0,16} \mathrm{Nd}_{0,08}\right)_{2,00}\left(\mathrm{Al}_{1,61} \mathrm{Fe}_{0,73} \mathrm{Mn}_{0,44} \mathrm{Mg}_{0,21}\right)_{2,99} \mathrm{Si}_{3,00} \mathrm{O}_{12}(\mathrm{O}, \mathrm{OH})$;

$6-\left(\mathrm{Ca}_{1,30} \mathrm{Mn}_{0,25} \mathrm{Ce}_{0,27} \mathrm{La}_{0,11} \mathrm{Nd}_{0,08}\right)_{2,00}\left(\mathrm{Al}_{1,94} \mathrm{Fe}_{0,91} \mathrm{Mg}_{0,07} \mathrm{Mn}_{0,01}\right)_{2,93} \mathrm{Si}_{3,07} \mathrm{O}_{12}(\mathrm{O}, \mathrm{OH}) ; 7-\left(\mathrm{Ce}_{0,56} \mathrm{La}_{0,44}\right) \mathrm{O}(\mathrm{OH}) ; 8-\mathrm{Fe}_{1,97} \mathrm{Ce}_{1,03} ;$

$9-\left(\mathrm{Ce}_{0,53} \mathrm{La}_{0,30} \mathrm{Nd}_{0,13} \mathrm{Pr}_{0,04}\right)\left(\mathrm{CO}_{3}\right)(\mathrm{OH}) ; 10-\left(\mathrm{Th}_{0,77} \mathrm{U}_{0,23}\right)_{1.00} \mathrm{O}_{2} ; 11-\left(\mathrm{Th}_{0,59} \mathrm{U}_{0,41}\right)_{1.00} \mathrm{O}_{2} ; 12-\left(\mathrm{Th}_{0,79} \mathrm{U}_{0,21}\right)_{1.00} \mathrm{O}_{2}$;

$13-\left(\mathrm{Th}_{0,92} \mathrm{U}_{0,08}\right)_{1,00} \mathrm{O}_{2} ; 14-\left(\mathrm{U}_{0,80} \mathrm{Th}_{0,20}\right)_{1.00} \mathrm{O}_{2} ; 15-\left(\mathrm{U}_{0,82} \mathrm{Th}_{0,15} \mathrm{Nd}_{0,03}\right)_{1.00} \mathrm{O}_{2} ; 16-\left(\mathrm{Zr}_{0,94} \mathrm{U}_{0,05}\right)_{0,99}\left(\mathrm{SiO}_{4}\right)_{1,01}$.

Площади: Широкопаднинская $(1,2,4-5,8,10-12,14,16)$, Мокрушинская $(3,13)$, Садовая $(6,7,9,15)$.

Таблица 3

Результаты изучения состава (мас. \%) минералов марганцевосиликатных пород Самаркинского террейна

\begin{tabular}{|c|c|c|c|c|c|c|c|c|c|c|c|c|c|c|c|}
\hline$№$ п/п & Минерал & $\mathrm{O}$ & $\mathrm{Al}$ & $\mathrm{Si}$ & $\mathrm{P}$ & $\mathrm{Ca}$ & $\mathrm{Mn}$ & $\mathrm{Sr}$ & $\mathrm{Zr}$ & $\mathrm{La}$ & $\mathrm{Ce}$ & $\mathrm{Nd}$ & $\mathrm{Th}$ & $\mathrm{U}$ & Сумма \\
\hline 1 & монацит & 28,41 & & 1,64 & 13,67 & 1,32 & & 1,02 & & 8,56 & 43,45 & 1,91 & & & 99,99 \\
\hline 2 & монацит & 26,61 & & 0,84 & 12,65 & & 2,49 & & & 7,54 & 35,64 & 9,13 & 2,95 & & 97,85 \\
\hline 3 & монацит & 40,96 & 0,66 & 20,23 & 7,09 & & & 2,07 & & 7,47 & 22,54 & 2,19 & & & 103,21 \\
\hline 4 & монацит & 27,92 & & 0,79 & 12,27 & 0,39 & 2,68 & & & 8,69 & 38,15 & 8,42 & & & 100,44 \\
\hline 5 & торнебомит & 25,45 & & 9,88 & & 0,24 & & & & 25,98 & 28,51 & 7,98 & & & 101,41 \\
\hline 6 & бастнезит & 9,83 & & 1,62 & & & & & & 18,04 & 41,77 & 7,58 & & & 78,83 \\
\hline 7 & гидроксид & 19,51 & & 2,09 & & & & & & 21,86 & 44,18 & 9,61 & & & 102,56 \\
\hline 8 & уранинит & 42,65 & 0,29 & 32,87 & & & & & 5,65 & & & & & 21,91 & 103,37 \\
\hline 9 & уранинит & 43,23 & & 34,88 & & & & & 3,35 & & & & & 22,11 & 103,57 \\
\hline 10 & уранинит & 15,64 & & 4,22 & & & 1,54 & & & & & & & 83,36 & 104,76 \\
\hline 11 & уранинит & 27,6 & & 9,06 & & & 12,73 & & 1,77 & & & & & 51,59 & 102,75 \\
\hline 12 & бреггерит & 12,7 & & & & & 2,62 & & & & & & 14,57 & 70,11 & 100 \\
\hline 13 & циркон & 34,64 & & 16,91 & & 0,28 & 14,04 & 1,76 & 27,5 & & & & & 1,82 & 96,95 \\
\hline 14 & циркон & 37,21 & & 14,93 & & & 4,07 & & 40,3 & & & & & 5,19 & 102,58 \\
\hline 15 & бадделиит & 48,35 & & 38,27 & & & & & 10,29 & & & & & 6,12 & 103,33 \\
\hline
\end{tabular}

Примечания: кроме того, в анализе $4-1,13 \mathrm{Sm} ; 5-3,39 \mathrm{Pr} ; 14-0,22 \mathrm{Mg}$ и 0,66 Hf; 15 - 0,29 Mg. Формулы:

$1-\left(\mathrm{Ca}_{0,08} \mathrm{Sr}_{0,03} \mathrm{La}_{0,14} \mathrm{Ce}_{0,71} \mathrm{Nd}_{0,03}\right)_{0,99}\left(\mathrm{PO}_{4}\right)_{1,01} ; 2-\left(\mathrm{Ce}_{0,64} \mathrm{La}_{0,14} \mathrm{Nd}_{0,16} \mathrm{Th}_{0,03}\right)_{0,97}\left(\mathrm{PO}_{4}\right)_{1,03} ; 3-\left(\mathrm{Ce}_{0,67} \mathrm{La}_{0,22} \mathrm{Nd}_{0,06} \mathrm{Sr}_{0,10}\right)_{1,05}\left(\mathrm{PO}_{4}\right)_{0,95} ;$

$4-\left(\mathrm{Ce}_{0,68} \mathrm{La}_{0,16} \mathrm{Nd}_{0,15} \mathrm{Sm}_{0,02}\right)_{1,01}\left(\mathrm{PO}_{4}\right)_{0,99} ; 5-\left(\mathrm{Ce}_{1,23} \mathrm{La}_{1,13} \mathrm{Nd}_{0,33} \mathrm{Pr}_{0,15} \mathrm{Ca}_{0,04}\right)_{2,88} \mathrm{Si}_{2,12} \mathrm{O}_{3,25} ; 6-\left(\mathrm{Ce}_{0,62} \mathrm{La}_{0,27} \mathrm{Nd}_{0,11}\right)\left(\mathrm{CO}_{3}\right)(\mathrm{OH})$;

$7-\left(\mathrm{Ce}_{0,55} \mathrm{La}_{0,28} \mathrm{Pr}_{0,05} \mathrm{Nd}_{0,12}\right)_{1,00} \mathrm{O}(\mathrm{OH})_{0,88} \mathrm{~F}_{0,06} \mathrm{Cl}_{0,02} ; 8-\left(\mathrm{U}_{0,60} \mathrm{Zr}_{0,40}\right) \mathrm{O}_{2} ; 9-\left(\mathrm{U}_{0,72} \mathrm{Zr}_{0,28}\right) \mathrm{O}_{2} ; 10-\mathrm{UO}_{2} ; 11-\left(\mathrm{U}_{0,92} \mathrm{Zr}_{0,08}\right) \mathrm{O}_{2}$;

$12-\left(\mathrm{U}_{0,82} \mathrm{Th}_{0,18}\right) \mathrm{O}_{2} ; 13-\left(\mathrm{Zr}_{0,92} \mathrm{Sr}_{0,06} \mathrm{U}_{0,02}\right) \mathrm{SiO}_{4} ; 14-\left(\mathrm{Zr}_{0,88} \mathrm{Hf}_{0,01} \mathrm{U}_{0,04}\right)_{0,93}\left(\mathrm{SiO}_{4}\right)_{1,06} ; 15-\left(\mathrm{Zr}_{0,81} \mathrm{U}_{0,19}\right) \mathrm{O}_{2}$ 
Таблица 4

Результаты изучения состава (мас. \%) минералов из силикатно-магнетитовых руд

\begin{tabular}{|c|c|c|c|c|c|c|c|c|c|c|c|c|c|}
\hline № п/П & Минерал & $\mathrm{O}$ & $\mathrm{Al}$ & $\mathrm{Si}$ & $\mathrm{P}$ & $\mathrm{Ca}$ & $\mathrm{Fe}$ & $\mathrm{La}$ & $\mathrm{Ce}$ & $\mathrm{Nd}$ & Th & $\mathrm{U}$ & Сумма \\
\hline 1 & монацит & 28,87 & & & 12,58 & & 3,6 & 10,42 & 25,36 & 11,11 & & & 94,27 \\
\hline 2 & $\mathrm{Dy}_{2} \mathrm{O}_{3}$ & 29,15 & & 0,47 & & & 42,55 & & & & & & 100,99 \\
\hline 3 & бастнезит & 14,48 & 0,32 & 0,45 & & & 7,83 & 18,44 & 37,73 & 5,54 & & & 87,58 \\
\hline 4 & гидроксид & 19,6 & 2,64 & 4,01 & & 0,23 & 26,12 & 13,24 & 28,47 & & & & 98,22 \\
\hline 5 & гидроксид & 24,06 & 0,62 & 0,85 & & 0,24 & 33,48 & 15,56 & 22,01 & & & & 96,83 \\
\hline 6 & апатит & 47,33 & 3,93 & 0,42 & 14,89 & 30,38 & 0,97 & 0,76 & & & & & 101,48 \\
\hline 7 & уранинит & 28,16 & 0,68 & & & & 49,18 & & & & & 23,94 & 103,11 \\
\hline 8 & бреггерит & 23,26 & & & & & 49,27 & & & 0,94 & 10,99 & 17,07 & 102,00 \\
\hline 9 & торианит & 21,35 & 0,51 & & & & 39,18 & & & & 31,42 & 13,24 & 106,15 \\
\hline 10 & торианит & 27,72 & & & & & & & & & 30,35 & 19,6 & 104,18 \\
\hline 11 & торианит & 31,5 & & 6,58 & 2,95 & & 4,39 & & & & 56,23 & & 101,64 \\
\hline
\end{tabular}

Примечания: кроме того, в анализе $1-0,33 \mathrm{~F}$ и 2,01 Sm; 2 - 27,96 Dy, 0,49 Tm и 0,36 Yb; 3-2,65 F и 0,15 Ni; $4-2,33 \mathrm{Mg}$, $0,55 \mathrm{~K}, 0,16 \mathrm{Ni}$ и $0,86 \mathrm{Zn} ; 6,9$ - 0,33 и 0,44 Mg, соответственно; 7 - 0,53 Ті и 0,64 Mn; 8 - 0,48 Mn. Формулы:

$1-\left(\mathrm{Ce}_{0,48} \mathrm{La}_{0,20} \mathrm{Nd}_{0,20} \mathrm{Sm}_{0,04}\right)_{0,92}\left(\mathrm{PO}_{4}\right)_{1,08} ; 2-\left(\mathrm{Dy}_{1,94} \mathrm{Tm}_{0,04} \mathrm{Yb}_{0,02}\right)_{2,00} \mathrm{O}_{3} ; 3-\left(\mathrm{Ce}_{0,61} \mathrm{La}_{0,30} \mathrm{Nd}_{0,09}\right)_{1,00}\left(\mathrm{CO}_{3}\right)\left[(\mathrm{OH})_{0,68} \mathrm{~F}_{0,32}\right]_{1,00}$; $4-\left(\mathrm{Ce}_{0,68} \mathrm{La}_{0,32}\right)_{1,00} \mathrm{O}(\mathrm{OH}) ; 5-\left(\mathrm{Ce}_{0,59} \mathrm{La}_{0,41}\right)_{1,00} \mathrm{O}(\mathrm{OH}) ; 6-\left(\mathrm{Ca}_{4,87} \mathrm{La}_{0,04}\right)_{4,91}\left(\mathrm{PO}_{4}\right)_{3,09}(\mathrm{OH}) ; 7-\mathrm{UO}_{2} ; 8-\left(\mathrm{U}_{0,57} \mathrm{Th}_{0,37} \mathrm{Nd}_{0,06}\right) \mathrm{O}_{2}$; $9-\left(\mathrm{Th}_{0,71} \mathrm{U}_{0,29}\right) \mathrm{O}_{2} ; 10-\left(\mathrm{Th}_{0,61} \mathrm{U}_{0,39}\right) \mathrm{O}_{2} ; 11-\mathrm{ThO}_{2}$.

В небольшом количестве REE иногда присутствуют в апатите и бреггерите. В монаците, алланите и других минералах из REE прибором обычно фиксируются только Ce, La и $\mathrm{Nd}$, реже $\mathrm{Pr}$, образующие относительно высокие концентрации. В анализах монацита и алланита иногда отмечается небольшое количество Sm и Gd. Содержание остальных REE и Y ниже уровня чувствительности. Алланит отличается относительно высокой суммой REE, среди которых преобладает Се, и высоким содержанием Mn. Обогащенный $\mathrm{Mn}(0,14-0,59$ ф.е.) алланит-(Cе) ранее обнаружен, в частности, в гранитоидах Японии [8]. Монацит из марганцевосиликатных пород представлен богатой Се разновидностью - монацитом-(Се). Характерными изоморфными примесями монацита в Таухинском террейне является Th, а в Самаркинском - Са и Sr. В гидроксилбастнезите и гидроксиде (?) иногда присутствует немного $\mathrm{F}$ или $\mathrm{Cl}$, а среди REE преобладает Се. Торианиту свойственно переменное, иногда высокое содержание U. Уранинит из марганцевосиликатных пород Самаркинского террейна обогащен Zr. Монацит, алланит, а также собственные минералы Th и U образуют мелкие включения в породообразующих минералах без признаков реакционных взаимоотношений (рис. 4). Алланит, кроме того, иногда присутствует в виде относительно крупных и многочисленных кристаллов, образующих равновесные срастания с породообразующими минералами, и, в частности, с диопсидом, магнетитом, родонитом и апатитом. Апатит в срастаниях с алланитом тоже обогащен REE. Гидроксид и бастнезит приурочены к участкам экзогенного изменения пород.

В силикатно-магнетитовых рудах Таухинского террейна минералы REE (см. табл. 4) представлены, главным образом, монацитом-(Cе) и Се-содержащим гидроксил-апатитом. В виде редких зерен встречают- ся бастнезит-(Ce), гидроксид $(\mathrm{Ce}, \mathrm{La}) \mathrm{O}(\mathrm{OH})(?)$ и соединение с идеальной формулой, предположительно, $\mathrm{Dy}_{2} \mathrm{O}_{3}$. Примесь REE иногда присутствует в бреггерите. В монаците, алланите и других минералах из REE прибором фиксируются только $\mathrm{La}, \mathrm{Ce}$ и (реже) $\mathrm{Nd}$, образующие относительно высокие концентрации. Кроме них в анализах иногда присутствуют небольшие содержания $\mathrm{Sm}, \mathrm{Gd}, \mathrm{Tm}$ или $\mathrm{Yb}$. Бастнезит относится к F-содержащей разновидности. К минералам Th и U относятся торианит, уранинит и бреггерит. Для торианита характерно переменное, иногда высокое содержание U. Монацит, обогащенный REE апатит и соединение $\mathrm{Dy}_{2} \mathrm{O}_{3}$, a также собственные минералы Th и U образуют мелкие включения в породообразующих минералах без признаков реакционных взаимоотношений (см. рис. 4).

\section{Обсуждение результатов исследований}

Метаморфизованные триасовые металлоносные осадки изначально являлись продуктами размыва латеритной коры выветривания (поздний анизий-конец триаса) габброидов сергеевского, владимиро-александровского и калиновского комплексов, накапливавшимися вместе с кремнистыми илами в прилегавших к островам акваториях. Кроме того, по геохимическим и изотопным данным в их составе присутствует вещество офиолитов (слагающих блоки в сергеевских габброидах) и континентальной окраины (предположительно, Ханкайского массива) [1].

Метаморфизованные триасовые металлоносные осадки имеют сложную геологическую историю, включающую периоды экзогенного выветривания, переноса и отложения продуктов разрушения габброидов, диагенеза и контактового метаморфизма, протекавшего местами при участии подвижной флюидной фазы метаморфогенной природы. Несмотря на 

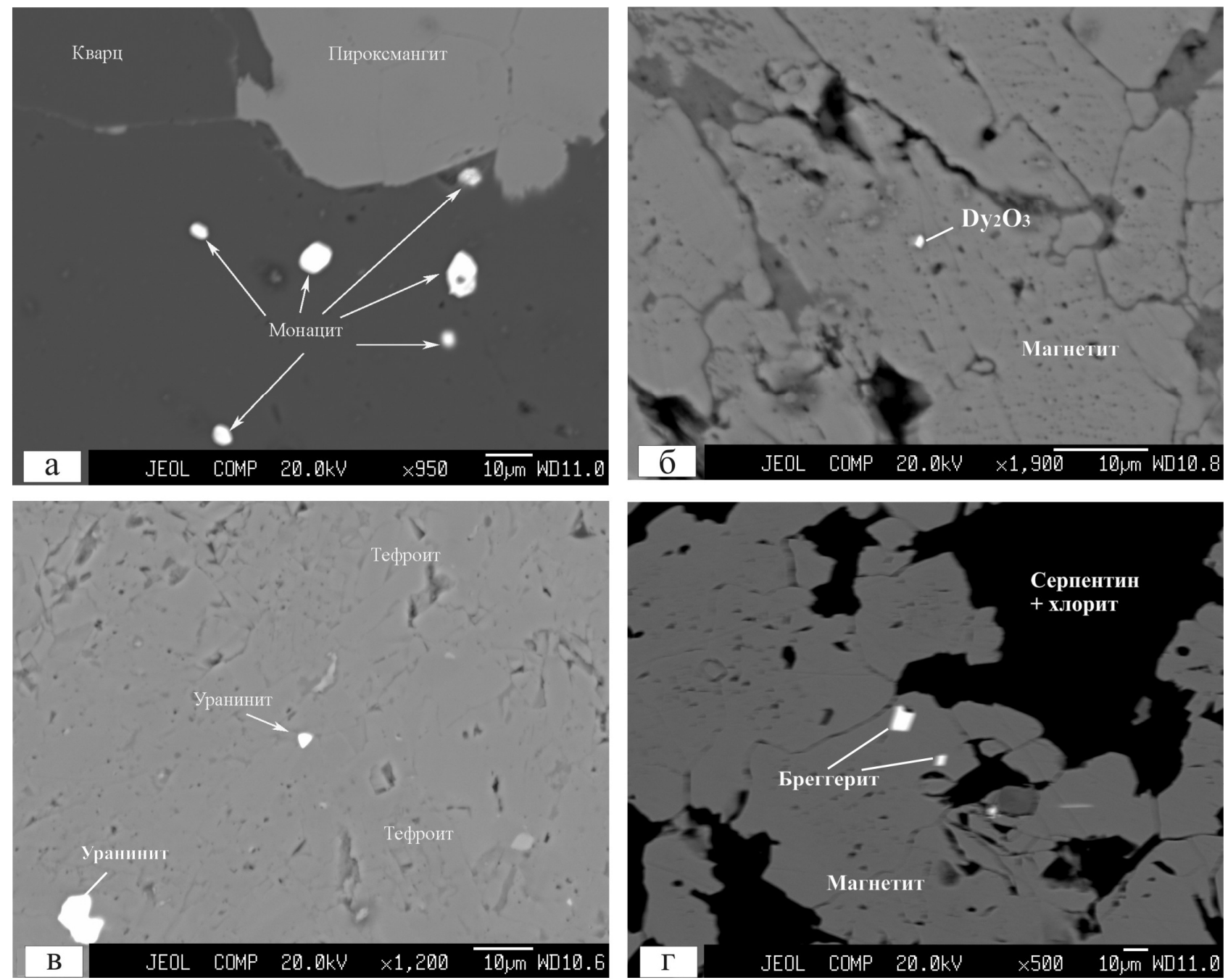

Puc. 4. Включения минералов REE (a, б), U и Th (в, г) в марганцевосиликатных породах (а, в) и силикатно-магнетитовых рудах $(б, г)$.

то, что эти процессы приводили к существенной дифференциации вещества магматических пород и его разбавлению инородным осадочным материалом (главным образом, биогенным кремнистым и органическим веществом), в метаморфизованных триасовых металлоносных осадках присутствуют некоторые геохимические и изотопные «метки» габброидов [1]. Отношения $\mathrm{Zr} / \mathrm{Y}$ и $\mathrm{Nb} / \mathrm{Y}$ в метаморфизованных металлоносных осадках Таухинского и Самаркинского террейнов определялись их отношениями в породах сергеевского и калиновского комплексов, соответственно. Отношения REE из-за значительной разницы их содержаний в породах сергеевского и калиновского комплексов (на один и более порядков), в обоих случаях определялись, главным образом, их отношениями в сергеевских габброидах (рис. 5). REE-спектры метаморфизованных металлоносных осадков по форме и наклону кривых близки к REE-спектрам габброидов сергеевского комплекса и резко отличаются от спектров калиновских габброидов (рис. 6, 7). Для них характерно обогащение легкими REE относительно тяжелых, наличие европиевого минимума, который обычно связывают с окислительно-восстановительными условиями [14] или с присутствием плагиоклаза в источнике расплавов [15], и гадолиниевого максимума. Последний обусловлен сочетанием европиевого минимума и т.н. «Gd-разрыва» [16] - одного из проявлений тетрадного эффекта. Его наличие в спектрах магматических пород обычно связывают с воздействием на расплав высокотемпературных водных флюидов и гидротермальных растворов [17, 18]. Европиевый минимум и гадолиниевый максимум присутствуют и в некоторых спектрах сергеевских габброидов. Для многих спектров метаморфизованных металлоносных осадков характерна Се аномалия (главным образом, положительная), появление которой связывают, в основном, с морскими обстановками [19] или с метасоматическими изменениями пород [20]. Присутствие в некоторых спектрах Се минимума, обычно с сопутствующей ему положительной $\mathrm{Eu}$ аномалией, обусловлено, вероятно, воздействием подвижной флюидной фазы. Предпринимавшиеся попытки использовать REE для реконструкции условий образования осадочных и метаморфических пород 

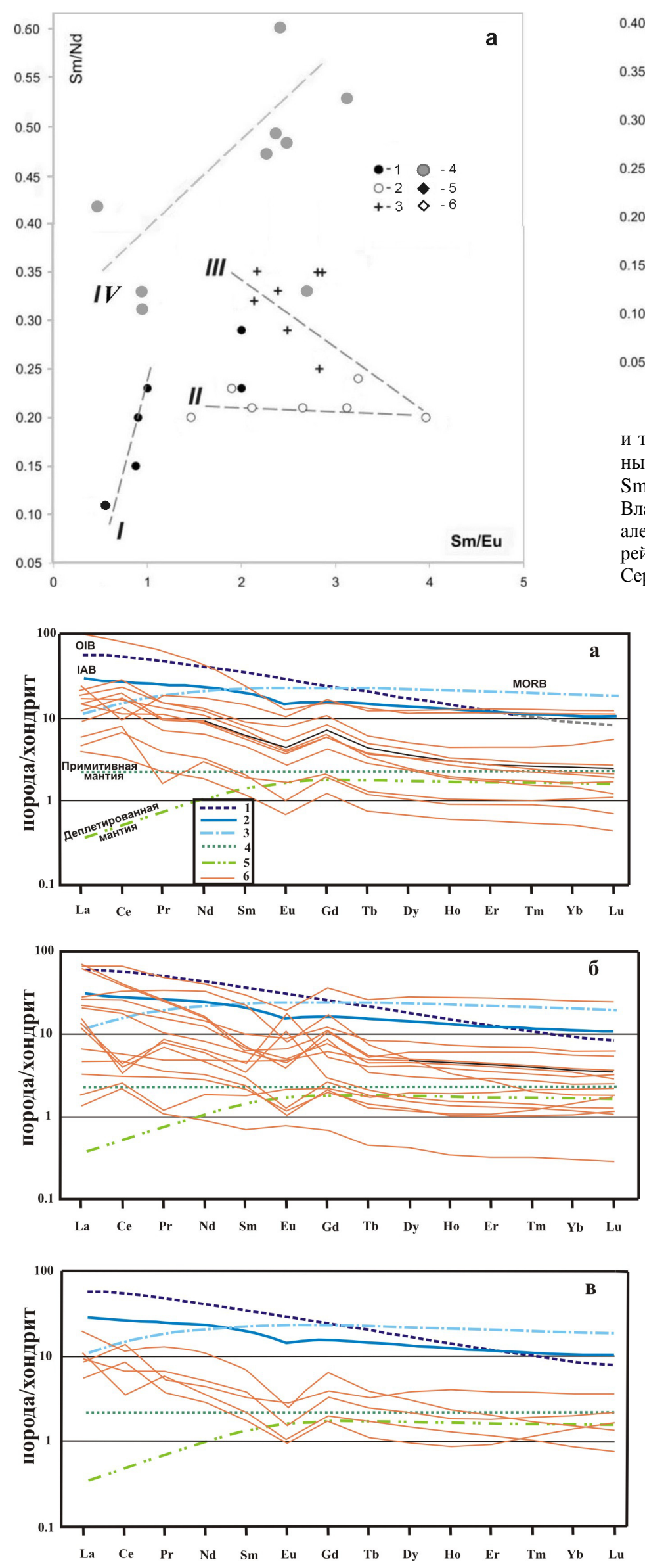

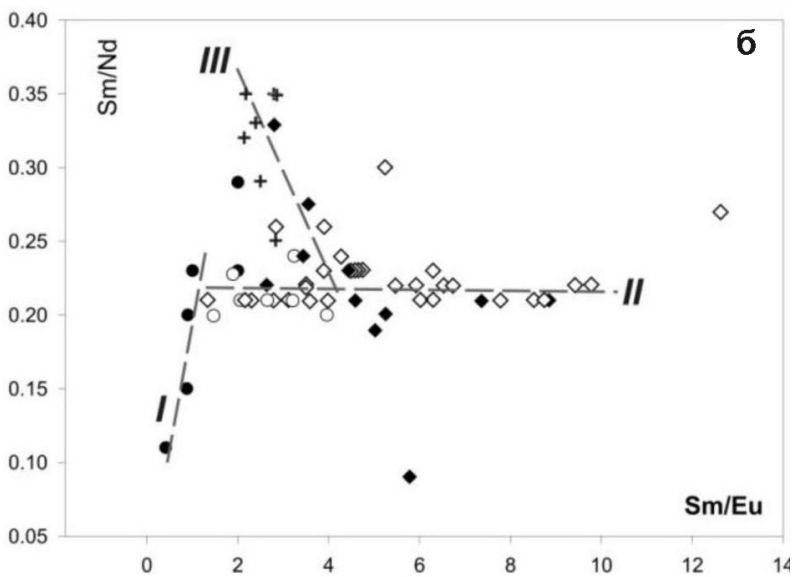

Puc. 5. Положение точек габброидов и офиолитов (а), и триасовых контактово-метаморфизованных металлоносных осадков Сихотэ-Алиня (б) на диаграмме « $\mathrm{Sm} / \mathrm{Nd}$ $\mathrm{Sm} / \mathrm{Eu} »[1,2]$. Магматические породы (1-4): ультрабазиты Владимиро-Александровского массива (1) (владимироалександровский комплекс); каменские (Самаркинский террейн, окрестности с. Каменка) и сергеевские (ОкраинскоСергеевский террейн, окрестности с. Сергеевка) габброиды

(сергеевский комплекс) (2) и офиолиты (3); бреевские габброиды (Самаркинский террейн, окрестности с. Верхняя Бреевка) (калиновский комплекс) (4).

Триасовые контактово-метаморфизованные осадки Сихотэ-Алиня $(5,6)$ : силикатно-магнетитовые руды (5) и марганцевосиликатные породы Горной площади Малиновского рудного района (6).

Тренды (I-IV): ультрабазитов Владимиро-Александровского массива (I), сергеевских и каменских габброидов (II) и офиолитов (Ш), бреевских габброидов (IV).

основываются на представлениях о том, что лантаноиды малоподвижны при диагенезе, катагенезе и метаморфизме осадков и отношения некоторых из них зависят от фациальных условий осадконакопления [21; 22]. Считается, что по мере увеличения глубины осадочного бассейна и отдаленности области осадконакопления от береговой линии возрастают коэффициенты $\mathrm{Yb} / \mathrm{Sm}, \mathrm{La} / \mathrm{Yb}$ и убывают $\mathrm{La} / \mathrm{Sm}$ и $\mathrm{Ce} / \mathrm{Sm}$. Средние значения коэффициентов $\mathrm{La} / \mathrm{Sm}$, $\mathrm{Ce} / \mathrm{Sm}, \mathrm{La} / \mathrm{Yb}$ и $\mathrm{Yb} / \mathrm{Sm}$ (см. табл. 1) для метаморфизованных металлоносных осадков Таухинского и Самаркинского террейнов близки и не зависят от их регионального положения или химического типа (марганцовистого или железистого).

Puc. 6. REE спектры марганцевосиликатных пород Горной (a) и Широкопаднинской (б) площадей и силикатно-магнетитовых руд Широкопаднинской площади (в): 1-5 - OIB (1), IAB (2), MORB (3), примитивная мантия (4); деплетированная мантия (5); 6 метаморфизованные триасовые металлоносные осадки.

Для нормирования содержаний и построения эталонных спектров использованы геохимические данные S.S. Sun, W.F. McDonough [9] (для OIB и MORB); M.T. McCulloch, J.A. Gamble [10] (для IAB); W.F. McDonough et al. [11]; D. A. Wood et al. [12] (для примитивной мантии); H.Palme, H.St.C. O'Neill [13] (для деплетированной мантии). 

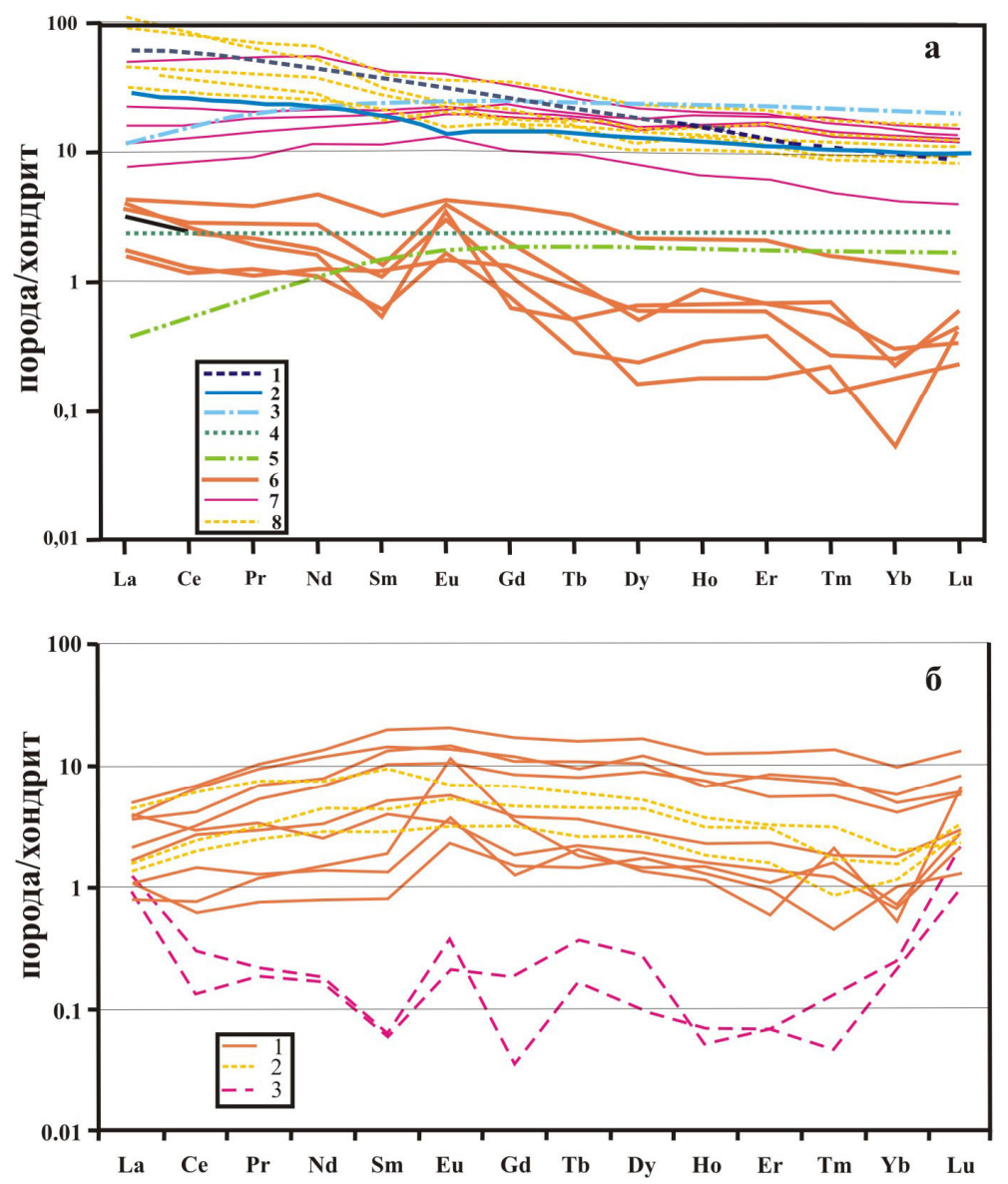

Puc. 7. REE спектры габброидов и офиолитов: $a-1-5$ - см. условные обозначения на рис. 6; 6-8 - владимироалександровские (6), сергеевские офиолиты (7) и габброиды (8); б - 1-2 - габброиды калиновские: Бреевский аллохтон (1) и массив Дальнего Кута (2); 3 - серпентиниты бухты Мелководной.

Они согласуются с величинами аналогичных коэффициентов для сергеевских габброидов $(3,81,8,05,9,04$ и 0,42 , соответственно), рассчитанных по ранее опубликованным данным [2]. Это позволяет сделать вывод об отсутствии, в данном случае, существенного влияния фациальных условий осадконакопления на распределение REE. Исключение составляет Ce-Sm отношение в марганцевосиликатных породах Горной площади, существенно большее, чем в сергеевских габброидах. Оно согласуется с присутствием положительной Се-аномалии почти во всех спектрах и обусловлено, вероятно, более близким расположением области накопления металлоносных осадков к окраине Ханкайского массива.

Монацит, алланит, обогащенный REE апатит и соединение $\mathrm{Dy}_{2} \mathrm{O}_{3}$, а также собственные минералы Th и $\mathrm{U}$ образуют включения в породообразующих минералах без признаков реакционных взаимоотношений и кристаллизовались в процессе метаморфизма в тех же условиях, что и породообразующие минералы марганцевосиликатных пород и силикатно-магнетитовых руд. Присутствие соединения $\mathrm{Fe}_{2} \mathrm{Ce}$, также как и многих других интерметаллидов и самородных элементов объясняется влиянием органического вещества «глинисто-кремнистой толщи» [7]. Оно связано с удалением из углеродистых пород при нагревании наиболее летучих компонентов, в первую очередь, плохо связанной воды и углеводородов, и возникновению, таким образом, некоторого объема флюида с высоко и ультравосстановительными способностями, мигрировавшего по трещинам в другие породы. Образование гидроксида (?) и карбоната REE возможно связано с экзогенными процессами.

Триасовые метаморфизованные металлоносные осадки Самаркинского и Таухинского террейнов отличаются по степени распространения тех или иных минеральных форм REE, главным образом, алланита и монацита. Эти различия кореллируют с различиями в минеральном составе парагенезисов породообразующих минералов и обусловлены региональными вариациями содержания Са в исходных осадках. Для относительно богатых Са марганцевосиликатных пород Таухинского террейна характерными минералами являются алланит и обогащенный REE апатит, а в аналогичных породах Самаркинского террейна распространен монацит. Эти различия объясняются более высоким содержанием Са в протолитах этих пород Таухинского террейна, которое при метаморфизме обеспечивало устойчивость алланита и способствовало связыванию Р в составе апатита. Оба этих обстоятельства были неблагоприятны для образования монацита.

Из собственных минералов Тh и U встречаются 
уранинит, бреггерит и торианит. Изоморфная примесь $\mathrm{Th}$ и U характерна для монацита и циркона, соответственно. Торий и U, кроме того, в виде изоморфной примеси присутствуют в цирконе и бадделиите. Циркону из марганцевосиликатных пород Таухинского террейна более свойственно наличие U, чем Hf. Минералы Th и U в метаморфизованных металлоносных осадках принадлежат, главным образом, к двум изоморфным рядам - торианит-уранинитовому и бадделиит-уранинитовому. Богатые $\mathrm{Zr}$ разновидности уранинита характерны только для марганцевосиликатных пород Самаркинского террейна. Для метаморфизованных металлоносных осадков Таухинского террейна характерен существенно ториевый тип минерализации (представленной, главным образом, U-содержащим торианитом и, в меньшей мере, бреггеритом), а Самаркинского - существенно урановый (преобладает не содержащий Тh уранинит, иногда очень богатый $\mathrm{Zr}$ ). Различная роль Th и U в составе Th-U минерализации согласуется с региональными вариациями их содержаний в метаморфизованных металлоносных осадках (см. табл. 1).

Несмотря на то, что Th и U присутствуют, главным образом, в виде собственных минералов, Th-U отношение обнаруживает отрицательную корреляцию с суммарным содержанием $\mathrm{Li}, \mathrm{Rb}$ и $\mathrm{Cs}$ (рис. 8) и с содержанием щелочей в триасовых метаморфизованных металлоносных осадках. Это наводит на мысль о первоначальном вхождении $\mathrm{Li}, \mathrm{Rb}, \mathrm{Cs}$ и U в слюдистые минералы исходных осадков, так как слюды являются щелочными минералами-концентраторами всех этих элементов. По-видимому, региональные вариации Тh$\mathrm{U}$ отношения определялись разным количеством слюдистого материала в исходных отложениях.

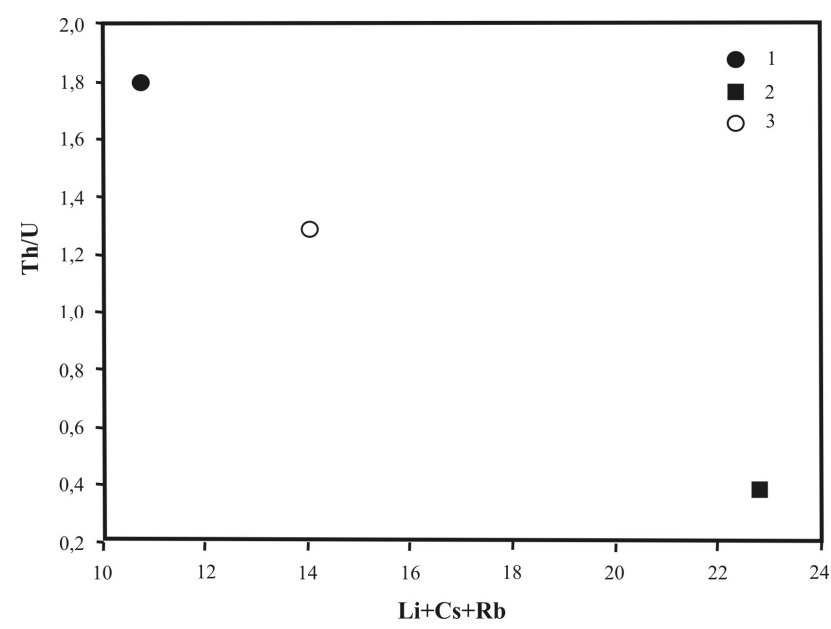

Puc. 8. Корреляция между средними значениями Th-U отношения и суммы $\mathrm{Li}, \mathrm{Cs}$ и $\mathrm{Rb}$ метаморфизованных триасовых металлоносных осадках Сихотэ-Алиня: 1, 2 - марганцевосиликатные породы Широкопаднинской и Горной площадей, соответственно; 3 - силикатно-магнетитовые руды Широкопаднинской площади.

\section{Заключение}

Несмотря на сложную геологическую историю, метаморфизованные триасовые металлоносные осадки, являющиеся продуктами размыва латеритной коры выветривания сергеевских, владимиро-александровских и калиновских габброидов, сохранили некоторые геохимические характеристики этих пород. Отношения REE (из-за значительной разницы их содержаний в породах сергеевского и калиновского комплексов) определялись отношениями этих элементов в сергеевских габброидах. По этой же причине REE-спектры по форме и наклону кривых также в целом довольно близки к REE-спектрам габброидов сергеевского комплекса. Наблюдаемые различия, наиболее выраженные в спектрах марганцевосиликатных пород Самаркинского (положительная цериевая аномалия) и Таухинского (отрицательная цериевая и положительная европиевая аномалии) террейнов связаны с различиями в фациальных условиях осадконакопления (определявшимися разным положением относительно окраины Ханкайского массива) и степенью влияния подвижной метаморфогенной флюидной фазы при метаморфизме, соответственно.

Метаморфизованные металлоносные осадки Таухинского и Самаркинского террейнов отличаются по степени распространения тех или иных минеральных форм REE, главным образом, алланита и монацита из-за региональных различий протолитов по содержанию Са.

Для метаморфизованных металлоносных осадков характерен существенно ториевый - в Таухинском, или существенно урановый - в Самаркинском террейне, типы торий-урановой минерализации, согласующиеся с высоким или низким Th-U отношением, соответственно. Региональные вариации Th-U отношения, обнаруживающего отрицательную корреляцию с суммарным содержанием $\mathrm{Li}, \mathrm{Rb}, \mathrm{Cs}$ и щелочей, определялись различным количеством слюдистого материала в исходных отложениях. Это заключение согласуется с наличием положительной Се аномалии в REE-спектрах марганцевосиликатных пород Самаркинского террейна и Ce-Sm отношением, свидетельствующими о накоплении исходных осадков в относительной близости к окраине Ханкайского массива.

Монацит, алланит, обогащенный REE апатит и соединение $\mathrm{Dy}_{2} \mathrm{O}_{3}$, a также минералы Th и U кристаллизовались в процессе метаморфизма в тех же условиях, что и породообразующие минералы метаморфизованных металлоносных осадков. Присутствие соединения $\mathrm{Fe}_{2} \mathrm{Ce}$, также как и многих других интерметаллических соединений и самородных элементов объясняется влиянием органического вещества «глинистокремнистой толщи». Оно связано с удалением из углеродистых пород при нагревании наиболее летучих компонентов, в первую очередь, плохо связанной воды и углеводородов, и возникновению, таким образом, некоторого объема флюида с высоко и ультравосстановительными способностями, мигрировавшего 
по трещинам в другие породы. Образование гидроксида (?) и карбоната REE возможно связано с экзогенными процессами.

\section{ЛИТЕРАТУРА}

1. Казаченко, В. Т. Геохимические и изотопные "метки" древних габброидов в триасовых метаморфизованных металлоносных осадках, скарнах и рудах скарновых месторождений Сихотэ-Алиня / В. Т. Казаченко, Е. В. Перевозникова, С. Н. Лаврик // Вестник Кольского научного центра РАН. - 4/2016 (27). - C. 16-36.

2. Габброиды сергеевского и калиновского комплексов Сихотэ-Алиня: геохимия и изотопные отношения самария, неодима, стронция и свинца / В. Т. Казаченко [и др.] // Вестник Кольского научного центра РАН. - 3/2015 (22). - С. 21 39.

3. Перевозникова, E. В. Марганцевосиликатные породы Южного Сихотэ-Алиня: минералогия и генезис: канд. дисс. / Е. В. Перевозникова - Владивосток, 2010. - 192 с.

4. Геодинамика, магматизм и металлогения Востока России / ред. А. И. Ханчук. - Кн. 1. - Владивосток: Дальнаука, 2006. $-572 \mathrm{c}$.

5. Казаченко, В. T. Петрология и минералогия гидротермальных марганцевых пород Востока России / В. Т. Казаченко. - Владивосток: Дальнаука, 2002. - 250 с.

6. Казаченко, В. T. Минералогия и генезис железомарганцевого оруденения Прибрежной зоны Приморья / В. Т. Казаченко, В. И. Сапин. - Владивосток: ДВО АН CCCР. 1990. - 248 c.

7. Казаченко, В. Т. Минералогия благородных металлов в марганцево-силикатных породах триасовой кремневой формации Сихотэ-Алиня / В. Т. Казаченко, Е. В. Перевозникова // Вестник Кольского научного центра РАН. - 2017. №3 (9). - C. 32-53.

8. Hoshino, M. Allanite-(Ce) in granitic rocks from Japan: genetic implications of patterns of ree and $\mathrm{Mn}$ enrichment / $\mathrm{M}$. Hoshino, M. Kimata, M. Shimizu // Can. Mineral. - 2006. - V. 44. - №1. - P. 45-62.

9. Sun, S. S. Chemical and isotopic systematics of oceanic basalts: implications for mantle composition and processes / S. S. Sun, W.F. McDonough // Magmatism in the Ocean Basins / A. D. Saunders and M. J. Norry. - Geological Society Special Publication, London. - 1989. - V. 42. - P. 313-345.

10. McCulloch, M.T. Geochemical and geodynamical constraints on subduction zone magmatism / M. T. McCulloch, J. A.

Дальневосточный геологический институт ДВО РАН, 2. Владивосток

Казаченко Валентин Тимофеевич, доктор геологоминералогических наук, главный научный сотрудник лаборатории нелинейной металлогении

E-mail:vkazachenko@mail.ru

Тел.: 89046258143

Перевозникова Елена Валериевна, кандидат геологоминералогических наук, старший научный сотрудник лаборатории нелинейной металлогении

E-mail: elenavalper@yandex.ru

Тел.: 8902556712
Gamble // Earth Planet. Sci. Lett. - 1991. - V. 102. - P. 358374.

11. $\mathrm{K}, \mathrm{Rb}$ and $\mathrm{Cs}$ in the esrth and moon and the evolution of the esrths mantle / W. F. McDonough [et al.] // Geochim. Cosmochim. Acta, Ross Taylor Symposium volum. - 1991. - V. 56. p. 1001-1012.

12. Elemental and $\mathrm{Sr}$ isotope variations in basic from Iceland and surrounding ocean floor / D. A. Wood [et al.] // Contrib. Mineral. Petrol. - 1979. - V. 70. - P. 319-339.

13. Palme, H. The Mantle and Core / H. Palme, H. St. C. O'Neill // Treatise Geochem. - 2003. - V. 2. - P. 1-38.

14. Bau, M. Rare-earth element mobility during hydrotermal and metamorphic fluidrock interaction and the significance of the oxidation state of europium / M. Bau // Chem. Geol. - 1991. Vol. 93. - P. 219-230.

15. Rollinson, $H$. Using geochemical data: evaluation, presentation, interpretation / H. Rollinson - New York, 1993. - 345 p.

16. Lottermoser, B. G. Rare earth elements and hydrotermal ore formation processes / B. G. Lottermoser // Ore Geol. Rev. 1992. - Vol. 7. - P. 25-41.

17. Lee, S. G. An early Proterozoic leuco-granitic gneiss with the REE tetrad phenomenon / S. G. Lee, A. Masuda, H. S. Kim // Chem. Geol. - 1994. - Vol. 114. - P. 59-67.

18. Tang, H. F. Trace element geochemistry during metamorphic dehydration: A case study from the Xingzi Group of Lushan, southeast China / H. F. Tang, C. Q. Liu // Geochem. J. 2002. - Vol. 36. - P. 545-561.

19. Скублов, С. Г. Геохимия редкоземельных элементов в породообразующих метаморфических минералах / С. Г. Скублов. - СПб.: Наука, 2005. - 147 с.

20. Перетяжко, И. С. Тетрад-эффекты в спектрах распределения редкоземельных элементов гранитоидных пород как индикатор процессов фторидно-силикатной жидкостной несмесимости в магматических системах / И. С. Перетяжко, Е. А. Савина // Петрология. - 2010. - Т. 18. - № 5. - С. 536566.

21. Балашов, Ю. А. Геохимия редкоземельных элементов / Ю. А. Балашов. - М.: Наука, 1976. - 265 с.

22. Шатров, В. А. Лантаноиды как индикаторы обстановок осадкообразования (на основе анализа опорных разрезов протерозоя и фанерозоя Восточно-Европейской платформы): автореферат диссертации на соискание ученой степени доктора геолого-минералогических наук / В. А. Шатров. Москва, 2007. - 36 с.

Far East Geological Institute of the Far-Eastern Branch of the $R A S$, Vladivostok

Kazachenko V. T., Dr. Sci. (Geology and Mineralogy), Chief

Researcher

E-mail:vkazachenko@mail.ru

Tel.: 89046258143

Perevoznikova E. V., PhD (Geology and Mineralogy), Senior Researcher

E-mail: elenavalper@yandex.ru

Tel.: 8902556712 